\title{
Informal Economy Dynamics as an Important Factor Defining Level of Social Unease
}

\author{
Gulnara Khadiullina, Elena Shurkina and Anna Svirina \\ Kazan National Research Technical University, Kazan, Russian Federation, Russia \\ Correspondence should be addressed to: Gulnara Khadiullina; verkbund@gmail.com
}

Received 24 November 2012; Accepted 26 June 2013; Published 28 November 2013

Academic Editor: Mihaela-Alina ROBU

Copyright (C) 2013 Gulnara Khadiullina, Elena Shurkina and Anna Svirina. Distributed under Creative Commons CC-BY 3.0

\begin{abstract}
The paper suggests the hypothesis that increasing level of social unease which can be seen in the world since the start of Arab spring is directly related to dynamics of informal economy. Subsequently in the paper some other suggestions are tested, including relation between the level of social unease and level of economic freedom, interrelation between the level of corruption and social unease which were not proven to be true. Quantitative testing of the above mentioned hypothesis proved there is direct relation between dynamics of informal economy and level of social unease.

Also the paper deals with the role of information accessibility, and it is defined that limitations of information access influence the informal economy dynamic's influence on social unease level. It is also suggested in the paper, and some argumentation is provided that current social unease is based on changing values and beliefs and informal economy dynamics is an important indicator of that process.
\end{abstract}

Keywords: Informal economy, social unease, values, social networking systems.

\section{Introduction}

2011 has been referred to as a year of social protests started with Arab spring and then witnessed bloodshed in Zhanaozen in Kazakhstan and White Ribbon movement in Russia, which appear to have a few common specific features. First of all, those movements seem to have no distinct leader - and henceforth they are quite different from Rose and Orange revolutions of mid-2000. Secondly, it usually looks like the aims of those social movements are quite unclear even for their leaders, and at the same time one is able to find very different people among participants of social protests. Finally, these protests are claimed to be connected with Internet based societies, since almost all of protesting communities were organized with a help of Facebook, YouTube or Twitter.

Nevertheless, currently the origin of 2011 protesting wave is unclear, and one can mention only De Soto's explanation concerning the reasons which lead to Arab spring. He claims "that to a great degree what you've got in the Middle East is an informal revolution: People who were outside the legal system and who would like to work in a legal system that supports them, which they can integrate. But it hasn't been designed yet. And I think what 
makes this interesting is the fact that the whole revolution is set off by informals. I mean it isn't set off by university students. It can be further carried out by university students, by political operators, but it starts out with the informal economy, which everybody identifies with, whether they understand what an informal economy is or not. They just know it's a situation of inferiority." (De Soto, 2011).

In this paper we would check this probable explanation using data from 100 different countries; we would also try to explain why social protests had outburst only in 2011 while informal sector in these countries had been growing during the first decade of XXI century, and in some cases - for the past twenty years. We would try to explore perspective and to define countries where social rebellions are most likely to occur in short-term perspective, and the main factors which affect such possibility.

\section{Theoretical Framework}

In order to move forward to making propositions we'd like to test in this paper, we need to define the meaning of term "informal economy" which we believe influences the behavior of people participating in social protests of 2011. Nowadays there are three main views on the contents and origin of informal economy:

1) The dualists (for example, ILO 1972) state, that that the informal sector is comprised of marginal activities distinct from and not related to the formal sector - that provide income for the poor and a safety net in times of crisis. According to this school, the persistence of informal activities is due largely to the fact that not enough modern job opportunities have been created to absorb surplus labor, due to a slow rate of economic growth and/or to a faster rate of population growth;

2) The stucturalist school (for example, Castells and Portes, 1989) subscribes to the notion that the informal sector should be seen as subordinated economic units (micro firms) and workers that serve to reduce input and labor costs and, thereby, increase the competitiveness of large capitalist firms. In the structuralist model, in marked contrast to the dualist model, different modes and forms of production are seen not only to co-exist but also to be inextricably connected and interdependent. According to this school, the nature of capitalist development (rather than a lack of growth) accounts for the persistence and growth of informal production relationships;

3) The legalists (for example, de Soto, 1989) claim that informal sector is comprised of micro-entrepreneurs who choose to operate informally in order to avoid the costs, time and effort of formal registration. According to De Soto, micro-entrepreneurs will continue to produce informally so long as government procedures are cumbersome and costly. In this view, unreasonable government rules and regulations are stifling private enterprise.

Since the authors are not planning to provide their own theoretical platform on informal economy, for the purposes of this study we have adopted legalists' approach, so we claim that informal economy appears in case formal registration is providing transactional costs which make entrepreneurial activity inefficient, and it is not important for what reason does this happen. Thus, we assume that informal economy grows as the consequence of high transaction costs arising from legalization of economic activity (the ones associated with defense of property rights, social safety, fulfillment of labor regulation legislative acts etc.) which become higher than avoidance of such costs by means of moving into informal sector of economy. Such transaction costs include 5 main elements as described by Eggertson (Eggertson, 1990) and Nort (Nort, 1981): 1) costs of finding and receiving information; 2) costs of quality estimation and control within the supply chain; 3) negotiations and contract costs; 4) property rights defense costs and 5) 
opportunistic behavior costs. All of those together cause increase of informal economy sector, which consists of the following elements: 1) household economics, 2) criminal economics, 3) tax avoidance economics, 4) unregistered economy and 5) administrative avoidance economy. Growth of informal economy sector in most cases leads to increase in transaction costs and henceforth to further growth of informal economy.

In order to achieve the goals of this research we are not planning to propose new methods of measuring informal economy (we believe this is another big research issue). In this paper the data from published surveys is used in order to investigate the following propositions.

Proposition 1. 2011 social protests are influenced by increased share of informal economy: all protesting countries had witnessed growth of informal economy share in the past decade and this trend was stable.

During data collection we have noticed that most of common people who took part in social protesting in 2011 were explaining the reasons of their "government opportunistic" behavior in terms of motivation and values. Henceforth in this paper we would need to test the role of motivation profile, and to do so we would use the theoretical framework for motivation and values assessment introduced by Richard Barrett (Barrett, 1997).We would argue that social protests occur in case people feel they are no longer sharing values with their governments, their motivation is focused on selfactualization and self-esteem level and values concern common good.
Proposition 2. 2011 social protests are influenced by the accessibility of information which can be available both from regular mass media sources and social networking systems which plays a role of certain filter and allows people to check experts' opinion which are quoted by regular mass media.

Finally, we would argue that suggested theoretical framework (see Figure 1) and measuring instrument can be used for prognosis of social unease outburst in the short-term period. By high information accessibility in this model we mean that any adult person is able to get access to any kind of information despite of its reliability; definition of informational quality is person's own responsibility.

\section{Research Methodology}

In order to test above mentioned propositions we would use correlation analysis which would allow us to define association between informal economy, economic freedom, and information availability and motivation profile on the basis of data from 100 countries in the past decade.

On the first stage of this research we have tested some propositions which are usually made in order to explain informal economy dynamics; for the purpose of this research we have calculated correlation between informal economy dynamics and level of economic freedom as well as relation between informal economy dynamics and level of corruption in the country, which are generally considered to be interrelated. The correlation was computed as classical Pearson correlation coefficient. 


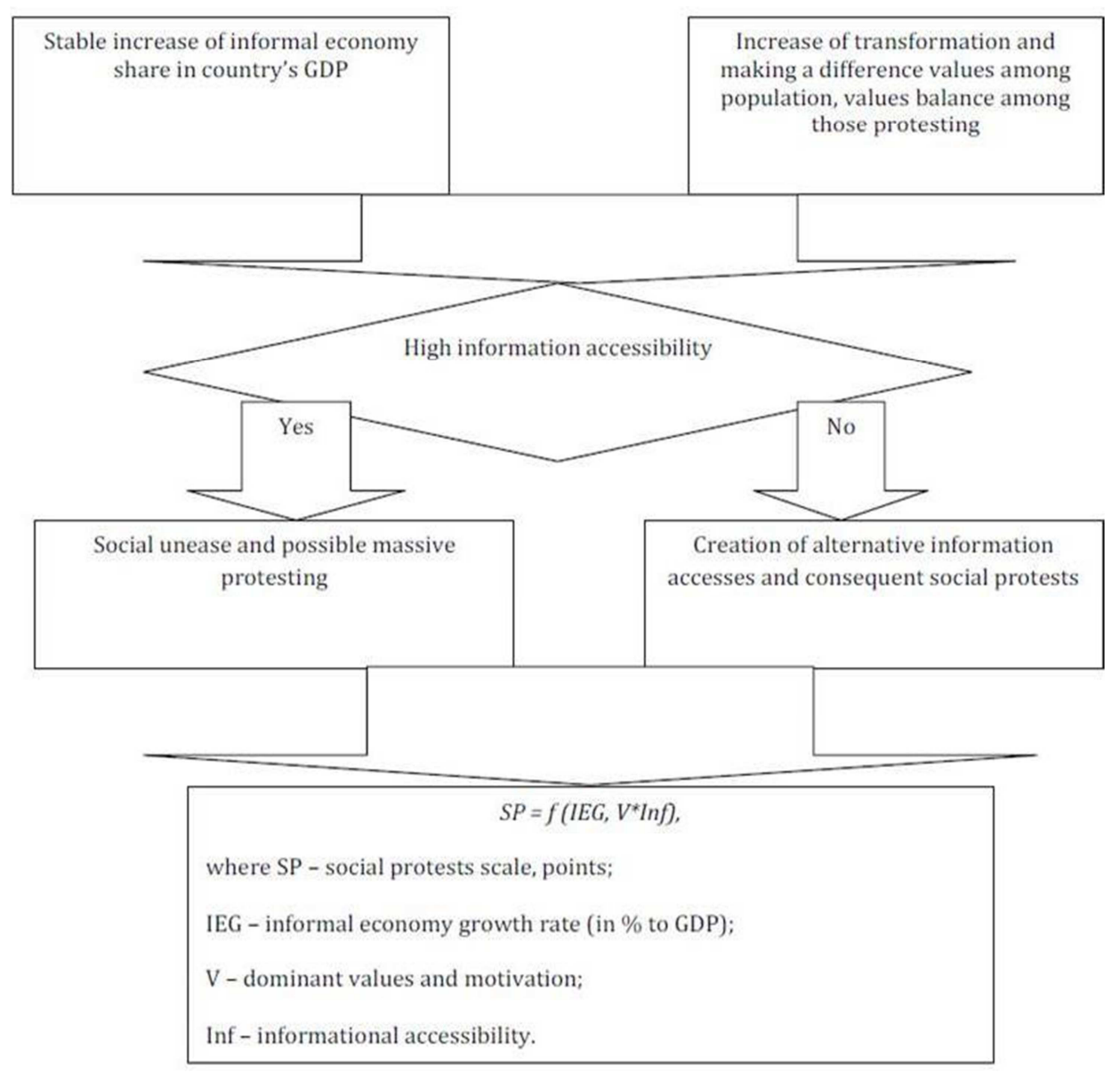

Figure 1. Theoretical Framework Model of the Survey

To measure the level of relation between the stated factors we have used the following variables: \% of GDP basic - this independent variable is used to define the share of informal economy at the bottom line of current research (year 2000 was chosen for that purpose due to the fact that in this year there was a global research of informal economy share done by World Bank); \% of GDP current - this independent variable which defines a share of informal economy in 6-9 years after the survey of World Bank (in order to define this variable we've tried to chose estimations carried by researches from the countries included in our research, who estimated the share of informal economy by using instruments which were the same or quite similar to the ones used by World Bank). Since those two variables come from different sources of data in order to make those figure comparable we have used dynamics of informal economy share, and not the absolute value.

The time distance between 2000 (bottom line of informal economy share estimation) and 2011 (start of social unease) may seem too big, but we took into account two assumptions: 1) we needed a relatively long period to estimate dynamics of informal economy share (for example, in case of Georgia there was an important change in dynamics after Rose revolution in 2003) and 2) we took into consideration the inertia of social systems (e.g. Roedenbeck, 2011).

The other methodological problem is the fact that countries like US, France or UK are brought together in a sample with the countries like Benin or Mali; however the 
reasoning behind such comparison was to see if suggested hypothesis work in case of every country.

\section{Social Protesting: Relation to Informal Economy, Economic Freedom, Level of Bribery and Corruption}

The data collected for informal economy dynamics was based upon results of World Bank informal economy report 2000 (Schneider, 2002), and later measuring of informal economy share to GDP in 100 sample countries (which included developed innovative driven economies, transition efficient and resource-based economies and undeveloped resource based economies) which were carried out by different authors and institutions (for example, Cling et al, 2010; Grim et al, 2011; OECD, 2009 and more than 10 other referred in References section) in past 5 years (the results can be seen in Table 1 ).

Table 1. Dynamics of Informal Economy Share Compared to GDP in Sample Countries

\begin{tabular}{|c|c|c|c|}
\hline Country & \% of GDP basic & $\%$ of GDP current & Dynamics $(+,-)$ \\
\hline Yemen & 27,4 & 54,2 & 26,8 \\
\hline Mali & 41 & 67,6 & 26,6 \\
\hline Benin & 45,2 & 70 & 24,8 \\
\hline Nicaragua & 45,2 & 66,7 & 21,5 \\
\hline Colombia & 39,1 & 58,5 & 19,4 \\
\hline Tunisia & 38,4 & 56,1 & 17,7 \\
\hline China & 13,1 & 28,8 & 15,7 \\
\hline Syria & 19,3 & 34 & 14,7 \\
\hline Kyrgyzstan & 39,8 & 53 & 13,2 \\
\hline Nepal & 38,4 & 51,47 & 13,07 \\
\hline Algeria & 34,1 & 45 & 10,9 \\
\hline Iran & 18,9 & 29,7 & 10,8 \\
\hline Nigeria & 57,9 & 67,3 & 9,4 \\
\hline Venezuela & 33,6 & 42,7 & 9,1 \\
\hline Azerbaijan & 60,6 & 69,6 & 9 \\
\hline Zambia & 48,9 & 56,7 & 7,8 \\
\hline Morocco & 36,4 & 44 & 7,6 \\
\hline Jordan & 19,4 & 26 & 6,6 \\
\hline Russia & 46,1 & 52,1 & 6 \\
\hline Ukraine & 52,2 & 58,1 & 5,9 \\
\hline Saudi Arabia & 18,4 & 24,2 & 5,8 \\
\hline Armenia & 46,3 & 51,7 & 5,4 \\
\hline Belarus & 48,1 & 53,1 & 5 \\
\hline Kazakhstan & 43,2 & 48,2 & 5 \\
\hline Vietnam & 15,6 & 20,1 & 4,5 \\
\hline Latvia & 39,9 & 44,3 & 4,4 \\
\hline Zimbabwe & 59,9 & 64,2 & 4,3 \\
\hline Cote d'Ivoire & 39,9 & 43,6 & 3,7 \\
\hline Bolivia & 67,1 & 70,7 & 3,6 \\
\hline Bosnia and Herzegovina & 34,1 & 36,7 & 2,6 \\
\hline Argentina & 25,4 & 27,8 & 2,4 \\
\hline Egypt & 35,1 & 37,2 & 2,1 \\
\hline Mozambique & 40,3 & 42,4 & 2,1 \\
\hline Costa Rica & 26,2 & 27,9 & 1,7 \\
\hline Chile & 19,8 & 21,4 & 1,6 \\
\hline Hong Kong & 16,6 & 18,2 & 1,6 \\
\hline Indonesia & 19,4 & 20,9 & 1,5 \\
\hline Poland & 27,6 & 29,1 & 1,5 \\
\hline Uruguay & 51,1 & 52,4 & 1,3 \\
\hline Mexico & 30,1 & 31,3 & 1,2 \\
\hline Panama & 64,1 & 65,2 & 1,1 \\
\hline Uganda & 43,1 & 44,2 & 1,1 \\
\hline
\end{tabular}




\begin{tabular}{|c|c|c|c|}
\hline Norway & 19,1 & 20,2 & 1,1 \\
\hline Ecuador & 34,4 & 35,4 & 1 \\
\hline Bangladesh & 35,6 & 36,4 & 0,8 \\
\hline Philippines & 43,4 & 44,1 & 0,7 \\
\hline Peru & 59,9 & 60,5 & 0,6 \\
\hline Jamaica & 36,4 & 36,9 & 0,5 \\
\hline Dominican Republic & 32,1 & 32,4 & 0,3 \\
\hline Italy & 27 & 27,2 & 0,2 \\
\hline Malawi & 40,3 & 40,2 & $-0,1$ \\
\hline Botswana & 33,4 & 33,1 & $-0,3$ \\
\hline Guatemala & 51,5 & 51,2 & $-0,3$ \\
\hline Burkina Faso & 38,4 & 38 & $-0,4$ \\
\hline Honduras & 49,6 & 49,2 & $-0,4$ \\
\hline Uzbekistan & 34,1 & 33,4 & $-0,7$ \\
\hline Croatia & 33,4 & 32,4 & -1 \\
\hline US & 8,8 & 7,2 & $-1,6$ \\
\hline Germany & 16,3 & 14,6 & $-1,7$ \\
\hline Kenya & 34,3 & 32,4 & $-1,9$ \\
\hline Madagaskar & 39,6 & 37,7 & $-1,9$ \\
\hline Turkey & 32,1 & 30,1 & -2 \\
\hline UK & 12,6 & 10,6 & -2 \\
\hline Bulgaria & 36,9 & 34,7 & $-2,2$ \\
\hline Japan & 11,3 & 9 & $-2,3$ \\
\hline New Zealand & 12,7 & 9,8 & $-2,9$ \\
\hline Netherlands & 13 & 10,1 & $-2,9$ \\
\hline Ireland & 15,8 & 12,7 & $-3,1$ \\
\hline Spain & 22,6 & 19,3 & $-3,3$ \\
\hline Denmark & 18,2 & 14,8 & $-3,4$ \\
\hline France & 15,3 & 11,8 & $-3,5$ \\
\hline Greece & 28,6 & 25,1 & $-3,5$ \\
\hline Sweden & 19,1 & 15,6 & $-3,5$ \\
\hline Canada & 16,4 & 12,6 & $-3,8$ \\
\hline Finland & 18,3 & 14,5 & $-3,8$ \\
\hline Lebanon & 34,1 & 30,3 & $-3,8$ \\
\hline Sri Lanka & 44,6 & 40,2 & $-4,4$ \\
\hline Australia & 15,3 & 10,7 & $-4,6$ \\
\hline Belgium & 23,2 & 18,3 & $-4,9$ \\
\hline Israel & 21,9 & 16,4 & $-5,5$ \\
\hline Ghana & 38,4 & 32,6 & $-5,8$ \\
\hline Czech Republic & 19,1 & 13,3 & $-5,8$ \\
\hline South Korea & 27,5 & 21,2 & $-6,3$ \\
\hline Hungary & 25,1 & 17,2 & $-7,9$ \\
\hline India & 63,2 & 54,8 & $-8,4$ \\
\hline Slovakia & 18,9 & 10,2 & $-8,7$ \\
\hline Thailand & 52,6 & 43,8 & $-8,8$ \\
\hline Singapore & 13,1 & 3,5 & $-9,6$ \\
\hline Albania & 33,4 & 23,4 & -10 \\
\hline Estonia & 12,9 & 2,3 & $-10,6$ \\
\hline Lithuania & 30,3 & 19,7 & $-10,6$ \\
\hline Mongolia & 18,4 & 7,5 & $-10,9$ \\
\hline Niger & 41,9 & 30,5 & $-11,4$ \\
\hline Romania & 34,4 & 21,1 & $-13,3$ \\
\hline Moldova & 45,1 & 31,6 & $-13,5$ \\
\hline Slovenia & 27,4 & 12,4 & -15 \\
\hline South Africa & 28,4 & 12,7 & $-15,7$ \\
\hline Brazil & 39,8 & 18,7 & $-21,1$ \\
\hline Tanzania & 58,3 & 34 & $-24,3$ \\
\hline Georgia & 67,3 & 39,1 & $-28,2$ \\
\hline
\end{tabular}

Gulnara Khadiullina, Elena Shurkina and Anna Svirina (2013), Journal of Economics Studies and Research, DOI: $10.5171 / 2013.720741$ 
As it had been already mentioned, in order to acquire appropriate data for this comparison, we have tried to find research which used similar to World Bank's methodology, or exactly the same. The other instrument we have used in order to achieve reliable results is the fact that we are comparing figures on dynamics, to obsolete figures, and this method allows high enough probability of results achieved. It is also worth mentioning that in case of developed countries such as US or UK the dynamics of informal economy share is small, while major changes take place in developing economies.

Economic Freedom Index was retrieved from Heritage foundation database (Heritage Foundation, 2011), and level of corruption and a sample on bribery were received from Transparency International database (Riano, Heinrich \& Hoddess, 2011; Hardoon\&Heinrich, 2011). Pearson correlation between economic freedom index and informal economy share dynamics appeared to be -0.1918 ; between the level of corruption and informal economy dynamics - +0.2129; between bribery and informal economy dynamics - 0.2717 . Those results prove that there is between level of economic freedom or corruption level and dynamics of informal economy is poor. This means that growth of informal economy is probably driven not by economic reasoning, or rather not only by economic reasoning, but by some effects which must be of social (or socioeconomic) origin.

In order to test this idea we have investigated if there were any types of social protests in the countries with high level of economic freedom. This analysis had proven that none of the countries which are economically free or mostly free had witnessed civil protesting in 2011 (except for "Occupy Wall Street" actions, but these ones, in our opinion, have a different origin and are coming from failed expectations). Nevertheless, Pearson correlation between the level of economic freedom and social unease level was estimated at the level of - 0.509, which means one can consider the level of economic freedom as one of the factors driving social uneasiness; however, the level of dependence proves there is negative association between those factors which can be considered an important one in case some extra research on the issue would be done.

The idea of interrelation between level of corruption and social protesting had been expressed by a number of authors (for instance, Burakova, 2011). This hypothesis was also tested on the country sample presented in Table 1: the result was that there is weak positive association between the level of corruption and social protesting (Pearson coefficient equals +0.4905 ), but this interdependence is even lower than the one between social uneasiness and economic freedom.

Finally, we have tested interrelation between social protesting and dynamics of informal economy - which was also the test for hypothesis expressed by De Soto (De Soto, 2011). In order to carry out this analysis we have used expert method for estimation of the level of social unease (using 100 point scale) where maximum figures stand for Arab spring rebellions such as Egyptian or Syrian ones (Libya was not tested due to the lack of data on Libyan informal economy). Than Pearson correlation coefficient was calculated to test association between growth rate of informal economy and social protesting level which fled out to the streets in 2011 (December 2010 in Belarus we have considered a part of this social protesting wave), and this coefficient was estimated at the level of +0.6907 which means there is positive association between the two. The list of economies which witnessed increase of informal economy share in GDP over $+2 \%$ and social protesting occurred in those countries can be seen in Table 2, from which it becomes clear that majority of the countries featured in this table had witnessed social protests. 
Table 2. Economies with Growing Share of Informal Sector and 2011 Social Protests

\begin{tabular}{|c|c|c|}
\hline Country & $\begin{array}{l}\text { Increase of informal } \\
\text { economy share in GDP, \% }\end{array}$ & Social protests \\
\hline Yemen & 26,8 & Arab spring \\
\hline Mali & 26,6 & \\
\hline Benin & 24,8 & \\
\hline Nicaragua & 21,5 & Ortega Facebook protests \\
\hline Colombia & 19,4 & Student protesting \\
\hline Tunisia & 17,7 & Arab spring \\
\hline China & 15,7 & \\
\hline Syria & 14,7 & Arab spring \\
\hline Kyrgyzstan & 13,2 & Tulip revolution, Kurban Bakiev overthrown \\
\hline Nepal & 13,07 & Red revolution \\
\hline Algeria & 10,9 & Arab spring \\
\hline Iran & 10,8 & Continuous rebellions \\
\hline Nigeria & 9,4 & 2010 rebellions \\
\hline Venezuela & 9,1 & 2010 rebellions \\
\hline Azerbaijan & 9 & 2011 rebellions \\
\hline Zambia & 7,8 & IMF protesting \\
\hline Morocco & 7,6 & Arab spring \\
\hline Jordan & 6,6 & Arab spring \\
\hline Russia & 6 & White ribbon protests \\
\hline Ukraine & 5,9 & Orange revolution \\
\hline Saudi Arabia & 5,8 & Arab spring \\
\hline Armenia & 5,4 & 2011 rebellions \\
\hline Kazakhstan & 5 & Zhanaozen rebellion \\
\hline Belarus & 5 & 2010-2011 rebellions \\
\hline Vietnam & 4,5 & Continuous rebellions \\
\hline Latvia & 4,4 & \\
\hline Zimbabwe & 4,3 & Mugabe ongoing rebellions \\
\hline Cote d'Ivoire & 3,7 & \\
\hline Bolivia & 3,6 & La Pas March \\
\hline $\begin{array}{l}\text { Bosnia and } \\
\text { Herzegovina }\end{array}$ & 2,6 & \\
\hline Argentina & 2,4 & Continuous protesting \\
\hline Egypt & 2,1 & Arab spring \\
\hline Mozambique & 2,1 & Arab spring \\
\hline
\end{tabular}

Those results prove that proposition 1 is true and social protesting in influenced by informal economy growth rate. This conclusion is also indirectly proven by the following fact: Rose revolution in Georgia had lead to dramatic decrease of informal economy size (from $67.3 \%$ in 2000 to $39.1 \%$ in 2006) and henceforth this country had not witnessed massive social protesting despite existing economic and political problems. This conclusion was also proven by the fact that $2^{\text {nd }}$ country in the list from Table 2 (Mali) had witnessed increasing social unease which led to war in 2012, and the level of this unease is quite high.

However, the achieved results, at first, did not let us find strong association between informal economy growth rate and social unrest level, do not explain the role of information access (by means of Internet 
social networks such as Twitter and Facebook) which seem to play important role in most protesting countries and do not provide any explanation why did people decide to protest after a long period of silence and obedience.

\section{The Role of Information Accessibility in Social Protesting}

As we have stated in theoretical framework of this paper (see Figure 1), we consider information accessibility to the one of the main factors of increased social protesting wave, but we believe this is not an independent factor but an auxiliary factor which affects people's motivation profile and dominating values. By full information accessibility in this paper we mean that it is possible for any adult person to gain access to any type of information via mass media, Internet sources or social networks; the question of trust and validity of information received by a person is his or her own responsibility (we consider, that in case different sources of information are available people would be able to decide whether information is trustworthy or not if they really want to do it). In order to test this hypothesis we have investigated interdependence between the level of social unease and accessibility of information within the country and between informal economy dynamics and the level of information accessibility. Both tests had shown weak negative association: for dependence between level of social unease and accessibility of information within the country Pearson coefficient for sample countries is equal -0.5759 , and for interdependence between informal economy dynamics and the level of information accessibility it is equal -0.48 for the same sample. This proves that there is some relation between accessibility of information and the level of social unease.

The other reason in favor of existence of relation between information accessibility and social unease scale can be received from qualitative analysis of Ukrainian and Georgian experience of successful social protesting: the Orange and Rose revolutions. The result of both was increased access to information; the opposite results where that in Georgia people had witnessed economic growth and that had proved to a certain amount of population that country can earn surplus wealth which is distributed within the country (so the prejudice in question was being partly driven out of people's minds), while in Ukraine economic path had gone back to redistribution of wealth, and henceforth the idea of impossibility of efficient reforms on the basis of civil protests was proven. At the same time in Georgia the share of informal economy after Rose revolution had decreased dramatically, while in Ukraine it was increasing.

Those facts had led us to testing the following hypothesis: we suggested that informational accessibility is influencing not social unease itself, but values and motivation of people. This can be proved by semantic analysis of main ideas expressed by participants who were pointing out that they are treated without any respect, being told they need to be guided since people themselves are unable to solve problems and at the same time those participants had witnessed high level of inefficiency in everything government was doing, and mentioned they were able to do it because they'd finally gained access to different sources of information. It was also proven by means of semantic analysis that informational restrictions had directly caused arising of the sense of citizenship, responsibility, desire for rule obedience and efficiency. In case information access is free the process of developing those values is natural and runs smoothly and evenly, while in case of restricted access to information people tend to seek all kind of sources providing data, and the process of developing values in question becomes spasmodic (uneven). On the next step of the process people suddenly become aware that they are not the only ones seeking information for analysis, and they are restricted to do so. This, in turn, provides a shift in motivation profile of potential protests participants towards self-esteem and self-actualization; at the same time understanding of need for common good values together with a feeling there is a team of people thinking along those lines 
becomes the starting point for social protesting wave - and on this stage society only awaits some catalyst to start protests. But the platform of the protesting is opposition of people's motivation and general trend of countries' disrespect for certain values. At the same time this process is uneven in case information access is restricted, henceforth less people than there could be are involved in social protesting.

In order to test the last thesis we have introduced information accessibility as a raising factor. The idea that information accessibility can become a factor of economic changes was proven for the situation of Indian women development which was associated with TV wide spreading within the country (Levitt\&Dubner, 2010). In this study we have adopted a similar idea. In case the country had no restrictions on information accessibility (in developed economies) multiplying coefficient was taken equal to 1 , which meant the scale of social protesting as estimated at the first step was maximum. In case there are economic restrictions (for example, some people in the country are unable to gain Internet access due to insufficient income) multiplying coefficient was introduced between 1.1-1.3. In case of Internet surveillance multiplying coefficient between 1.3-1.5 was introduced and it was increased if there were both surveillance and economic barriers present in informational environment of the country. Finally, maximum multiplying coefficient equal to 2 was introduced for so-called "enemies of the Internet" which were observed in this study - China, Iran, Saudi Arabia, Syria, Uzbekistan and Vietnam, where one can find official restrictions imposed on information access. Those coefficients were estimated by the experts in Delphi method way when each expert was asked to do the same estimation twice after three week break. We have also taken into consideration the fact that in case regular mass media are censored in the country, information accessibility is dependent on the availability of independent sources of information, first of all on Internet based resources, which means that mainly relatively prosperous citizens have maximum access to information in order to analyze current situation.

Pearson correlation calculated for checking interrelation between informal economy growth rate and level of social unease corrected by the level of information accessibility is equal +0.7209 which means there is strong positive association. Correlation of relative growth rate of informal economy share and social protesting corrected by the level of information accessibility is even higher (high positive association, correlation coefficient is equal +0.7446$)$. Henceforth, the higher is growth rate of informal economy as share of GDP, the higher is the chance that social protests are going to occur in the country. If this is true governments can postpone social uneasiness by means of information suppression, but in case citizens would get access to information riots would just tend to become more violent (on the opposite, in countries where information suppression is minimum peaceful social protesting is more likely to occur).

Finally we have checked correlation between the share of informal economy and social protests movement (which could have been another reason for social unease). This test was, as we felt, necessary, since the two countries which were part of Arab spring but witnessed decrease of informal economy share (Burkina Faso and Lebanon) had the share of informal economy over 30\% which is considered dangerous for country's economic development. Pearson correlation between the share of informal economy and level of social unrest appeared to be equal to +0.1575 which means there is no association between the two. Henceforth we can definitely state that it is informal economy dynamics that matters, but not its share in the economy.

According to above described results we can state that main propositions expressed in this paper had been proven by qualitative and quantitative analysis, which 
allows us to make some prognosis on the issue of social unease.

\section{Conclusions}

Results of research allow us to make the following conclusions:

1. Governments in the countries from risk zone (and growing social unease can be seen, for example, in China as latest Communists party congress and previous events had shown) need to take into consideration necessity to lessen the share of informal economy in order to decrease social unease. In that context Georgia when reaction had started after latest elections would be a good case study.

2. It is also important for businesses and governments to understand that in case of growing informal economy share in environment providing access to information one needs to expect growing ratio of concerned people and appearance of social networking systems which tend to replace existing governmental and business structures in order to satisfy their needs.

3. Regarding future research this paper proposes the need for monitoring situation in countries from the risk zone, as well as those who'd shown decrease in growth rate of informal economy and where governments had changed during election period. This data would allow to either prove or disclaim hypothesis stated in this paper.

4. For the needs of future research it is also important to create a model for measuring informal economy share which would allow to lessen disadvantages of existing approaches.

\section{References}

Barrett, R. (1997). 'Building a ValuesDriven Organization,' ButterworthHeinemann.
Barrett, R. (2011). Stages in the Evolution of Democracy, www.valuescentre.com. Retrieved on 31.12.2011.

Becker, K. F. (2004). 'The Informal Economy: Fact Finding Study,' SIDA

Bernabe, S. A. (2002). A Profile of Informal Employment: The Case of Georgia, International Labor Office, Geneva

Burakova, L. A. (2011). 'Why Did Georgia Succeed,' Alpina Business Books. (In Russian).

Cling, J.- P., Nguyen, T. T. H., Nguyen, H. C., Razafindrakoto, M., Roubaud, F. \& Constance, T. (2010). 'Comparing Informal Sector in Vietnam and Africa,' Hanoi: The Gioi Editions.

De Soto, H. (1989). The Other Path: The Economic Answer to Terrorism, Harper Collins.

De Soto, H. (2011). Hernando de Soto on the Middle East's 'Informal' Revolution, http://www.marketplace.org/topics/busin ess/economy-40/hernando-de-sotomiddle-easts-informal-revolution.

Retrieved on 30.12.2011.

Eggertson, T. (1990). Economic Behavior and Institutions, Cambridge Surveys of Economic Literature series. Cambridge University Press.

Friedrich, S. (2002). 'Size and Measurement of the Informal Economy in 110 Countries around the World,' Workshop of Australian National Tax Center, ANU.

Grimm, M., Lay, J., Roubaud, F. \& Vaillant, J. (2011). Informal Sector Dynamics in Times of Fragile Growth: The Case of Madagascar, Document de Travail UMR DIAL.

Hardoon, D. \& Heinrich, F. (2011). Bribe Payers Index 2011, Transparency International.

Heritage Foundation. '2011 Index of Economic Freedom,' http://www.heritage.org/index/ Retrieved on 30.12.2011. 
ILO. (1972). 'Employment, Incomes and Equality: A Strategy for Increasing Productive Employment in Kenya. Report of an Inter-agency Team Financed by the United Nations Development Programme and Organised by the International Labour Office,' ILO, Geneva.

Krstic, G. \& Sanfey, P. (2007). Mobility, Poverty and Well-Being among Informally Employed the Bosnia and Herzegovina, European Bank for Reconstruction and Development Working Paper.

Kuehn, Z. (2007). Tax Rates, Governance, and the Informal Economy in High Income Countries, Madrid.

Levitt, S. D. \& Dubner, S. J. (2010). Superfreakonomics, Moscow: Ivanov, Mann and Faber. (In Russian).

Nort, D. C. (1981). Structure and Change in Economic History, Norton.

OECD. (2009). Competition Policy and the Informal Economy, Policy Roundtable Report.

Oxford Analytica. (2011). Kyrgyz and Tajik Shadow Economies Impede Development, Oxford Analytica.

Petkov-Bulgaria, K. (2009). Policies and Measures to Formalize the Informal Economy, ILO-ITC Seminar on "Employment and Informal Economy".

Portes, A., Castells, M. \& Benton, L. A. (1989). "The Informal Economy: Studies in Advanced and Less Developed Countries," Baltimore: John Hopkins University, 11-37.

Puffer, S. M. \& McCarthy, D. J. (2011). "Two Decades of Russian Business and Management Research: an Institutional Theory Perspective," Academy of Management Perspectives.

Renooy, P., Ivarsson, S., van der WustenGritsai, O. \& Meijer, R. (2004). Undeclared Work in an Enlarged Union. DirectorateGeneral for Employment and Social Affairs Final Report. Brussels.
Riano, J., Heinrich, F. \& Hoddes, R. (2010). Global Corruption Barometer 2010, Transparency International.

Roedenback, M. R. H. (2011). "Individual Path Dependency and Social Inertia: Facing the Crudeness of Sociology," Journal of Future Studies, 15 (4): 25-44.

Saakashvili, M. (2011). Final Report of Georgian President in 2004. www.civil.ge/rus/article.php?id=6817, Retrieved on 26.12.2011.

Skinner, C. (2011). AAPS Planning Education Toolkit: The Informal Economy, University of Capetown, South Africa, 2011. http://www.scribd.com/doc/61223136/In formal-Economy-Toolkit-1. Retrieved on 26.12.2011.

Stavitskyi, V. (2011). Informal Economy and SLIP Agenda in Russia and Hungary, Master of Arts Degree Thesis. Budapest.

Suwal, R. \& Pant, B. (2009). "Measuring Informal Sector Economic Activities in Nepal," IARIW-SAIM Conference on "Measuring the Informal Economy in Developing Countries". Kathmandu.

Takim, A. (2011). 'Effectiveness of the Informal Economy in Turkey,' European Journal of Social Sciences, 19, 2, 2011.

The Informal Sector: What is It, Why Do We Care, and How Do We Measure It? http://siteresources.worldbank.org/INTLA C/Resources/CH1.pdf. Retrieved on 28.12.2011.

The Informal Sector and the State: Institutions, Inequality and Social Norms, http://siteresources.worldbank.org/INTLA C/Resources/CH8.pdf. Retrieved on 28.12.2011.

The Urban Informal Sector in China. http://wenku.baidu.com/view/d82dc0f90 242a8956bece404.html. Retrieve on 30.12.2011. 
Tunyan, B. (2005). The Shadow Economy in Armenia: Size, Causes and Consequences, Armenian International Policy Research Group Working Paper. Yerevan.

Verick, S. (2005). "The Impact of Globalization on the Informal Sector of Africa," United Nations Economic Commission for Africa.

Vuletin, G. J. (2008). Measuring the Informal Economy in Latin America and the Caribbean, International Monetary Fund Working Paper. IMF.

Webb, J. W., Tihanyi, L., Ireland, R. D. \& Sirmon, D. G. (2009). "You Say Illegal, I Say Legitimate: Entrepreneurship in the Informal Economy," Academy of Management Review, Vol. 34, No. 3. 